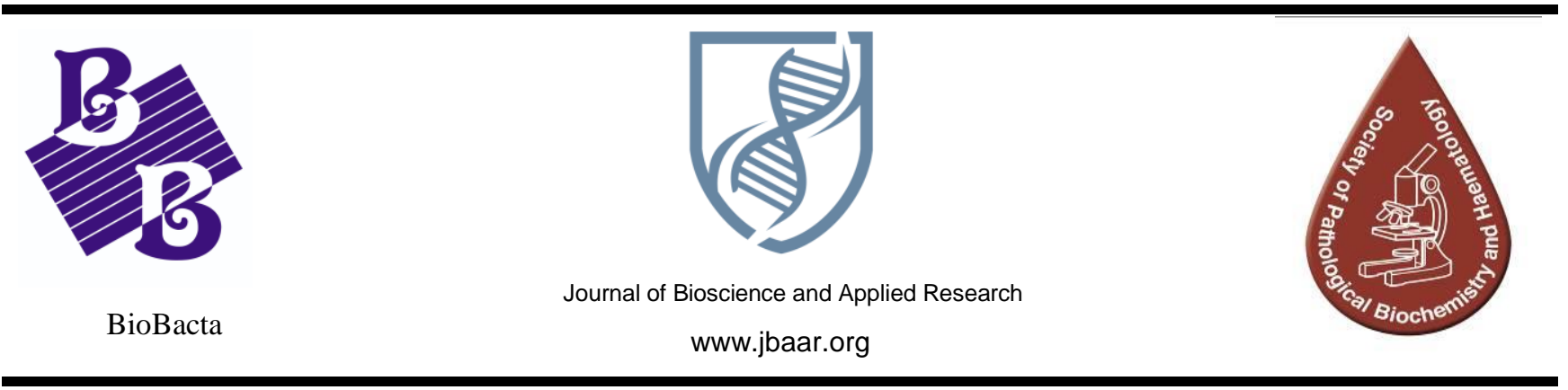

\title{
Factors Contributing to Perinatal Mortality in a Sample of Hospitals in the Health Directorate of Baghdad Al-Karkh in April 2018 - March 2019
}

\author{
Fawzi H. Atshan ${ }^{1}$, Ibtesam F. Hassan ${ }^{1}$, Munir T. Salman ${ }^{1}$, and Basim M. jwad ${ }^{2}$ \\ ${ }^{1}$ DR.Fawz iHashim Atshan; Public Health Department / Baghdad Health Directorate - Al-Karkh \\ ${ }^{1}$ DR.Ibtesam Farage Hassan; Public Health Department / Baghdad Health Directorate - Al-Karkh \\ ${ }^{1}$ DR.Munir Talib Salman; Public Health Department / Baghdad Health Directorate - Al-Karkh \\ ${ }^{2}$ Dr. Basim M. Jwad; Department of pathology and poultry diseases, Collages of Veterinary Medicine, \\ University of Baghdad, Baghdad, Iraq. \\ bassim.m@covm.uobaghdad.edu.iq Mobile; Viber \& WhatsApp: (009647903310288).
}

Received: July 18, 2020. Accepted: August 30, 2020. Published: September 14, 2020

\begin{abstract}
:
The Perinatal mortality rate is an important index of community health condition and quality of health service provided to the mother and their fetus during the 28 weeks of gestation till, after delivery, there are many factors that threaten their life. This study aimed to determine the perinatal mortality rate in Baghdad AL Karkh health directorate and to identify the contributing factors and main causes of perinatal mortality. A study based on a record review of the perinatal mortality in three hospitals in Baghdad Al-karkh for a one year starting from $1^{\text {st }}$ April 2018 and at the end in March 2019. The total deliveries were 27,096, while the total deaths were 1217 deaths during the perinatal period the perinatal mortality rate was $45 / 1000,67 \%$ of them with newborn death, $57 \%$ of fetal gender was male, $64 \%$ of perinatal deaths were delivered by cesarean section, the most common maternal contributing factors is the complication of labor and delivery was $24 \%$ while the fetal causes are Respiratory and cardiovascular disorders specific to the perinatal period was $56 \%$, the study revealed a significant relation or association between gestational age, mode of delivery, place of delivery, a product of delivery and age of the baby when dead and in another side this study revealed a no association between the mother's age, gender of the baby and the Weight of the baby. The main causes of perinatal mortality deaths occur during the first 2 days and may be modifiable with simple targeted perinatal policies with, quality improvement of the health care providing in labor rooms and neonatal care units.
\end{abstract}

Keywords:-perinatal mortality rate, risk factors, stillbirths, quality improvement. 


\section{Introduction:}

Statistics show that, every five second, nearly ten human die, and any random person currently has a $0.5 \%$ chance of dying within the year. Despite the ever-present threat of death, in some places it seems a more common event than others (1) According to a 2014 report by CIA World Fact Book, some countries have markedly low mortality rates, and the oil-rich nations in and around the Arab Gulf claim some of the lowest yet so the crude death rates, that include Qatar, United Arab Emirates, Kuwait, Bahrain, Oman, KSA, and Iraq are $(1.53 \%, 1.97 \%, 2.18 \%$, $2.69 \%, 3.36 \%, 3.33 \%$ and $3.77 \%$ /death rate"'1 per $1,000 "$ ) respectively (2).

Over 130 million babies are born every year. The perinatal mortality rate is five times higher in developing than in developed regions, 10 deaths per 1000 total births in developed regions; 50/1000. On the other side, it is highest in Africa, with 62 deaths per 1000 births, while the perinatal mortality rate in Asia is 50 per 1000 total births (3). The perinatal mortality rate (PMR) is an important indicator of the quality of obstetric care during pregnancy $(4,5)$. PMR includes deaths that occur due to obstetric events, stillbirths, and early neonatal mortality (ENM) occurring within seven days after birth (6). Neonates are at most risk of dying in their first week of birth, and globally three-quarters of neonatal deaths occur in the first week. Even in high-income settings where the quality of medical services and resources is high, policies to reduce the PMR are still needed, and as much as $25 \%$ of perinatal mortality in developed countries is estimated to be preventable by the achievement of optimal standards of care quality (7).

The terminology, that was review at 2016, which standard terminology for (fetal, infant, and perinatal deaths), that established by the American Academy of Pediatrics (AAP), through a clinical report based on standards set of the National Center for Health Statistics (NCHS) of the Centers for Disease Control and Prevention (CDC), and World Health Organization (WHO) (8).
The (WHO) defines stillbirth as at or after 28 weeks gestation, whereas a report of National Center for Health Statistics was referring to fetal deaths, that occur $\geq 20$ weeks gestation, which also known as (stillbirth), on the other hand, and the NCHS further subdivides fetal death pending to statistical purposes, to "late" that happen during ( $\geq 28$ weeks gestation), or "early" that take place at (20 to 27 weeks gestation) (9).

The current research was conducted aiming to measure the Perinatal mortality rate in the three main hospitals at the health directorate of Baghdad AlKarkh region during a year period from the first of April 2018 to the end of March 2019) and to identify the contributing factors and causes to perinatal mortality.

\section{Material and methods:-}

A review of hospital records (death records) was conducted on a file of perinatal mortality records at three main hospitals in Baghdad AL-Karkh District at a period of one year from $1^{\text {st }}$ April 2018 - End of March 2019. Those three hospitals, provide delivery care and had a labor unit and intensive newborn care unit (Al-Yarmouk Teaching Hospital, Al-Imamin Kadhimin Medical City, and Al-Mahmoudiyah District Hospital). These hospitals serve a large geographical area from Baghdad City. The data of study have been chosen followed as; Data related to perinatal deaths (hospital medical record) was obtained from the hospitals included in this study. Also, data related to the number of live births were obtained from the Department of Planning /section of Health and Vital Statistic in Bagdad Al-Karkh Directorate.

The sample size of all perinatal deaths that occurred during the period of one year from (1st April 2018 End of March 2019), and the information was obtained from the medical record of the deceased baby. Permission was taken from the Department of Health and also from an authorized manager at each selected hospital. 
Data software was analyzed via [Statistical Package for Social Science-version 16.0 (SPSS-16)], that used in order to describe the data. Chi-Square test was used to find the relationship between the variables of the study where P- value less than 0.05 reveal that high statistically significant between the variables.
The formula that used to calculate the perinatal mortality rate is based on (10) that appear pregnancies resulting in fetal deaths that occur through $(\geq 20$ weeks) from gestation, categorized as miscarriages, is:-

\section{(Early neonatal deaths + stillbirths)}

Perinatal mortality rate $=$ $x 1000$

( Total births (live births + stillbirths ).

\section{Result and Discussion:-}

The perinatal deaths were (44.9/1000), live births (still births mortality rate per 1000 live births was (14.9), and neonatal mortality rate per 1000 live births was (30.0), that recorded in Table1. which shows the highly statistical difference between the selected hospitals. During this study, the total deliveries were 27096 all are recorded in selected hospitals the total perinatal deaths were 1217 deaths, the highest deaths reported in Al-Yarmouk teaching hospital were 681, then in the Al-Imamin Kadhimin Medical City were 496, and the lowest in Al-Mahmudiyah hospital were 40. This has been drawn in Figure 1, that shows that most of the perinatal death in the first two days of life and decrease the number of deaths with an age of the baby.

Table-1 also shows the perinatal mortality rate distribution (newborn death /1000 live births and Rate of still births $/ 1000$ total births in selected hospitals. The perinatal mortality rate in Al-Yarmouk teaching hospital was $681(54.220 / 1000)$ as total deaths, from (12318) live births; which higher than in Al-Imamin Kadhimin Medical City, and AlMahmudiyah hospital were $496(42.663 / 1000)$ as total deaths, from (11477) live births; 40 (13.746/1000) as total deaths, from (2896) live births, respectably, Whilst the total perinatal deaths, were 1217 (44.914/1000) as total deaths, from (26691) live births.

Table1: Total deliveries and perinatal deaths in health directorate of Baghdad Al-Karkh.

\begin{tabular}{|l|c|c|c|c|c|c|}
\hline \multirow{2}{*}{ Health facilities } & Total births & live births & \multicolumn{2}{|c|}{ No. of Perinatal deaths } & \multicolumn{2}{|c|}{ Total deaths } \\
\cline { 4 - 6 } & & & Stillbirths & New born deaths & \multicolumn{2}{l|}{} \\
\hline Al-Yarmouk Teaching Hospital & 12560 & 12318 & $242(35.5 \%)$ & $439(64.5 \%)$ & 681 & $54.220 / 1000$ \\
\hline Al-ImaminKadhimin Medical City & 11626 & 11477 & $149(30.04 \%)$ & $347(69.96 \%)$ & 496 & $42.663 / 1000$ \\
\hline AL- MahmudiyahHospital & 2910 & 2896 & $14(35.0 \%)$ & $2665.0(\%)$ & 40 & $13.746 / 1000$ \\
\hline Grand total & 27096 & 26691 & $405(33.28 \%)$ & $812(66.72 \%)$ & 1217 & $44.914 / 1000$ \\
\hline
\end{tabular}






Figure1: Perinatal death during 1st week of life according to days after delivery in Bagdad AL-Karkh.

Regarding the age of the mothers, table 2 shows the relationship between variables of the majority of women (64\%) at age (20-29 years). Whereas, (54\%) of perinatal deaths were male was no significant, and $(76 \%)$ of them delivered before 37 weeks of gestation ( premature babies ) was significant. regarding the body Wight at delivery was $69 \%$ with body weight less than $(2.500 \mathrm{~kg})$ was no significant and the mode of delivery (64\%) by the cesarean section was significant. Finally (90\%) were singleton was significant at (Apr.2018 - Aug.2019).

Table 2: The distribution of deaths by different variables.

\begin{tabular}{|c|c|c|}
\hline Characteristics & Frequency & Percentage \\
\hline Age of mother (years); Less than 20 & 67 & 5.5 \\
\hline $20-29$ & 780 & 64.1 \\
\hline $30-39$ & 293 & 24.1 \\
\hline 40 and more & 77 & 6.3 \\
\hline Gender of baby; Male & 658 & 54.1 \\
\hline Female & 559 & 45.9 \\
\hline Gestational age (weeks); 28-32 & 462 & 38.0 \\
\hline $33-36$ & 458 & 37.6 \\
\hline 37 and more & 297 & 24.4 \\
\hline Birth Weight (grams); Less than 1000 & 190 & 15.6 \\
\hline $1000-1499$ & 184 & 15.1 \\
\hline $1500-1999$ & 232 & 19.1 \\
\hline $2000-2499$ & 233 & 19.1 \\
\hline 2500 and more & 378 & 31.1 \\
\hline Mode of delivery; Normal vaginal delivery & 435 & 35.7 \\
\hline Cesarean section & 782 & 64.3 \\
\hline Age of baby at death;Still births & 405 & 33.3 \\
\hline Newborn deaths & 807 & 66.3 \\
\hline Products of delivery; Singleton & 1095 & 90.0 \\
\hline Twin and more & 122 & 10.0 \\
\hline
\end{tabular}


The maternal risk factors that contribution effects with perinatal mortality and perinatal causes, in Baghdad AL-Karkh region at a period (Apr.2018 March.2019), was documented in (Table: 3), it shows the main maternal contribution factors lead to perinatal deaths according to (ICD-10) was "Other complications of labour and delivery mostly is caesarean delivery and preterm labour and delivery", it was represented (24\%), while the main cause related to the fetus was "Respiratory disorders specific to the perinatal period" represented (56\%).

Table 3: Maternal Risk Factors of Perinatal Mortality and perinatal causes according to ICD-10 classification in Baghdad AL-Karkh.

\begin{tabular}{|c|c|c|c|}
\hline \multicolumn{2}{|r|}{ Maternal Risk Factors of Perinatal Mortality } & Frequency & Percentage \\
\hline \multicolumn{4}{|c|}{ Maternal condition } \\
\hline 1 & $\begin{array}{l}\text { The complications of labour and delivery mostly is Caesarean delivery and } \\
\text { preterm labour and delivery }\end{array}$ & 290 & 23.8 \\
\hline 2 & $\begin{array}{l}\text { Maternal medical and surgical conditions; noxious Influences mostly is. pre- } \\
\text { eclampsia / eclampsia }\end{array}$ & 151 & 12.4 \\
\hline 3 & $\begin{array}{l}\text { Complications of placenta, cord and membranesmostly is other forms of } \\
\text { placental separation and hemorrhage }\end{array}$ & 127 & 10.4 \\
\hline 4 & No maternal conditionor healthy mother & 133 & 10.9 \\
\hline 5 & $\begin{array}{l}\text { Maternal complications of pregnancy mostly ispreterm rupture of } \\
\text { membranes. }\end{array}$ & 104 & 8.5 \\
\hline 6 & Mixed 3 and 1 (Add them to 3 and to 1 ) recalculate the $\%$ again & 161 & \\
\hline 7 & Unknown & 63 & 5.2 \\
\hline \multicolumn{4}{|c|}{ Perinatal causes } \\
\hline 1 & Respiratory disorders specific to the perinatal period & 702 & 57.7 \\
\hline 2 & Congenital malformations, deformations and chromosomal abnormalities & 207 & $\mathbf{1 7 . 0}$ \\
\hline 3 & Prematurity complication & 160 & 13.1 \\
\hline 4 & Other disorders originating in the perinatal period & 101 & 8.3 \\
\hline 5 & Infections specific to the perinatal period & 84 & 6.9 \\
\hline
\end{tabular}

The perinatal mortality reflects the suboptimum quality of maternal and child health services, and the selected hospitals for this study are the busiest, best equipped, and staffed, serving wide geographical rural and urban areas in the Al-Karkh health directorate. The perinatal mortality was (45 per 1000) live births, which higher than in the Dhok and Sulaymania where the authors Abdul-malik and Abdul-razaq, whereas in 2013 state that perinatal mortality in Duhok governorate (24.5 per 1000) live birth (13 and 14).

Study of Abdulhameed and Aljammas 2015 the perinatal mortality in Sulaymania was 25/1000 live birth 15, the author Samira T. Abdulghani, 2012 stat manifested (50.3 /1000 live birth) perinatal mortality, in Fallujah general hospital (15). In northern Ghana, during 2013, state that nearly two-thirds $(64.8 \%)$ of the 424 neonatal deaths, is occurred in the first week of life half of all neonatal deaths (46\%) occurred in the first three postnatal days, which mimic the result of current study due to the prematurity complications (16).

There is no significant association between age of the mother and perinatal death in this study because about $64 \%$ of the mother age was (20-29), where the study of $(17 ; 18$ and 19) reveal that "increase in the risk of neonatal mortality among neonates those born to young mothers aged 13-19 years compared with those whose mother's aged 20-34 years. Also, there is no significant association between the sex of 
newborn and perinatal death rate in the present study which not matching with the study of Baloch which reveals a significant association between sex of newborn and perinatal death where the $(\mathrm{p} \leq 0.001)$ (20). Male babies were born more frequently than female babies (male to female ratio 1.06) with approximately 4 babies per 10,000 born of indeterminate sex or (unknown sex) (21).

The gestational weeks there is a significant association between the gestation age and perinatal deaths the same as the result of Australian study "gestational age Stillbirth and neonatal mortality rates declined with increasing gestational age to 38 weeks' gestation, with the lowest rates between 38 and 41 weeks' gestation. The stillbirth and neonatal mortality rates increased again after 42 weeks" (22). The resulting study of (23), was "Between 34 and 40 weeks' gestation, the FD risk of those remaining undelivered for all pregnancies declined and then increased at term. The no any significant association between the weight of the baby and perinatal death where the mean weight of all deliveries in this study more than $2000 \mathrm{mg}$ and the study of (24)reveal that "Very low birth weight babies $(<1500 \mathrm{~g})$ had 10 times mortality rates than babies with birth weight between $1.5-2.5 \mathrm{~kg}$ ".

The significant association between $\mathrm{s} / \mathrm{c}$ and perinatal deaths this supported by the study of (25), whose show "There was also a significant increase in the Caesarean section rate with advancing maternal age. The main Maternal Risk Factors which are contributing to Perinatal Mortality has included the "the complications of labour and delivery mostly is caesarean delivery and preterm labour and delivery" was $26 \%$ included mainly case are a delivery, preterm labour and delivery, for that, the present study reveals that the $1^{\text {st }}$ cause of perinatal deaths is due to the respiratory problems which represented (56\%) like the first cause of perinatal deaths worldwide was $(36 \%)$, in another side the 2nd cause of perinatal deaths of this study is due to the congenital malformation was (17\%) unlike the $2^{\text {nd }}$ cause of perinatal deaths worldwide was and globally due to premature complication which represented (28\%) but the $3^{\text {rd }}$ cause of perinatal deaths of this study is due to the premature complication which represented (13\%) (26).

There is some variation between countries depending on their care configurations and even in different governorates of the same country, there are several studies done in Al-Amara City, Al-Sulaymania city, Duhok city (28;29 and 30), were reveal the variation between these governorates where the main cause of neonatal deaths is due to Respiratory problems were $62 \%, 85 \%, 37 \%$ respectively, in another side the main cause of neonatal deaths is Congenital anomaly in Japan, Sweden, respectively 48, 29 (25).

In conclusion, the present study revealed a high perinatal mortality rate than the most neighbouring Arab countries, the early perinatal mortality deaths remain a significant problem in Bagdad Al-karkh. From the other hand, the main causes of perinatal mortality deaths occur during the first 48 hours of life and may be modifiable with simple targeted perinatal policies with.

\section{Conflict of Interests Statement:-}

The authors declare that there is no conflict of interests regarding the publication of this article.

\section{Acknowledgement:-}

We would like to express our deep gratitude and appreciation to the \{Public Health Department / Baghdad Health Directorate - Al-Karkh \} to support, for completing this work. Also, We would like to express grateful to the main hospitals at Baghdad ALKarkh District (Al-Yarmouk Teaching Hospital, AlImamin Kadhimin Medical City and AlMahmoudiyah District Hospital), for providing me with the essential requirements for completing this work.

\section{References:}

1. Nelson R, Staggers N. Health Informatics-EBook: An Interprofessional Approach. 2nd Edition.Elsevier Health Sciences; Printed in China. 2016, Unit-2; Pp. 91-111.

2. Dillinger Jessica. "Lowest Death Rates Worldwide." WorldAtlas, (Accessed on Apr. 25, 
2017). "worldatlas.com/articles/the-countrieswith-the-lowest-death-

rates."https://www.worldatlas.com

3. Word health organization WHO. Neonatal and Perinatal Mortality Country, Regional and Global Estimates: 2006.

WS:16. www.WHO.org.(Accessed on Des.4.2006).

4. Richardus JH, Graafmans WC, VerlooveVanhorick SP, Mackenbach JP. The perinatal mortality rate as an indicator of quality of care in international comparisons. Med. care. 1998 1:5466.

5. Richardus JH, Graafmans WC, VerlooveVanhorick SP, Mackenbach JP, EuroNatal International Audit Panel, EuroNatal Working Group, A list of the members of the EuroNatal International Audit Panel and the EuroNatal Working Group may be found on page 104. Differences in perinatal mortality and suboptimal care between 10 European regions: results of an international audit. BJOG: An International Journal of Obstetrics and Gynaecology. 2003. 110(2):97-105.

6. Lander T. World Health Organization (WHO) Neonatal and perinatal mortality: country, regional, and global estimates 69.2006.(Accessed on Des.4.2006).

7. Lawn JE, Cousens S, Zupan J. million neonatal deaths: when? where? why? Lancet.[Internet]. 2004 [cited 2013 June 04], 365 (9462): 891-900.

8. MacDorman MF, Gregory EC. Fetal and perinatal mortality: United States, 2013."National vital statistics reports.2015". 64(8) 2015-1120.

9. Vogel JP, Souza JP, Mori R, Morisaki N, Lumbiganon $\mathrm{P}$., et al. Maternal complications and perinatal mortality: findings of the World Health Organization Multicountry Survey on Maternal and Newborn Health. BJOG: An International Journal of Obstetrics and Gynaecology. 2014. 121:76-88.

10. UNICEF D. Monitoring the situation of children and women. New York: United Nations
Children's Fund; 2017.(Accessed on Sep.21.2015).

11. World Health Organization (WHO). Making Every Baby Count: Audit and Review of Stillbirths and Neonatal Deaths. Geneva: WHO; 2016. .(Accessed on Oct..9.2016).

12. Barfield WD. Standard terminology for fetal, infant, and perinatal deaths. Pediatrics. 2016. 1,137(5):e20160551.

13. National Center for Health Statistics Website. www.cdc.gov/nchs (Accessed on July 20, 2011).

14. Srivastava S, Sharma S, Kharkwal S, Chaudhary V. A study of causes of perinatal mortality in tertiary center in Bundelkhand region. IJRCOG. 2015. 4(1):44.

15. Nayyef NK, Al-Bairmani JK, Al-Hillali AM. Perinatal and neonatal mortality, risk factors, and causes in Babylon teaching hospital for maternity and children during 2018. Medical Journal of Babylon. 2020. 17(1): 58-63.

16. Abdulhameed AL, Aljammas EK. Perinatal mortality in Sulymania teaching hospital. World J Pharm Pharm Sci. 2016. 5(10):158-70.

17. Samira T A, Yaseen Taha S, Abdulsattar Kadhem L. Perinatal and neonatal mortality in Fallujah General Hospital, Fallujah City, Anbar Province, west of Iraq. Health. 2012.4 (9):597-600.

18. Welaga P, Moyer CA, Aborigo R, Adongo P, Williams J., et al. Why are babies dying in the first month after birth? A 7-year study of neonatal mortality in northern Ghana. PLoS One. 2013. 8(3):e58924.

19. Selemani M, Mwanyangala MA, Mrema S, Shamte A, Kajungu D., et al. The effect of mother's age and other related factors on neonatal survival associated with first and second birth in rural, Tanzania: evidence from Ifakara health and demographic surveillance system in rural Tanzania. BMC pregnancy and childbirth. 2014. 14(1):240.

20. Neal S, Channon AA, Chintsanya J. The impact of young maternal age at birth on neonatal mortality: Evidence from 45 low and middle 
income countries. PLoS One. 2018.13(5): e0195731.

21. Sharma V, Katz J, Mullany LC, Khatry SK, LeClerq SC., et al., Young maternal age and the risk of neonatal mortality in rural Nepal. Archives of pediatrics and adolescent medicine. 2008. 162(9):828-35.

22. Zhao D, Zou L, Lei X, Zhang Y. Gender differences in infant mortality and neonatal morbidity in mixed-gender twins. Scientific reports. 2017. 7: 8736

23. Peelen MJ, Kazemier BM, Ravelli AC, De Groot CJ, Van Der Post JA., et al. Impact of fetal gender on the risk of preterm birth, a national cohort study. Acta Obstet Gynecol Scand. 2016. 95(9):1034-41.

24. Myers SA, Waters TP, Dawson NV. Fetal, neonatal and infant death and their relationship to best gestational age for delivery at term: is 39 weeks best for everyone? J. Perinatol. 2014. 34(7):503-7
25. Sangamam R. Perinatal mortality and morbidity among low birth weight babies. IJCMPH. 2017. 2(1):51-8.

26. Tripathy P. Clinical characteristics \& morbidity pattern among Low Birth Weight Babies. IJSRP. 2014.4(4)::20-30yrs.

27. Alrahmman SA. Incidence and probable risk factors of stillbirth in Maternity Teaching Hospital in Erbil city. Zanco J. Med. Sci.2015. 19(3):1057-1062.

28. Luna VA. Grieving Behaviors During Parental Bereavement in Western Societies.2018."World health organization WHO.(2015).Main causes of children deaths". (Accessed on April 5, 2018).

29. Alsadi E. Comparison study of causes and neonatal mortality rates of newborns admitted in neonatal intensive care unit of Al-Sadder Teaching Hospital in Al-Amara City, Iraq. Int. J. Pediatr. 2017. 5(3): 4601-4611.

30. Al-Ani ZR, Al-Hiali SJ, Al-Mashhadani WS. Perinatal mortality rate in Al-Ramadi Maternity and Children's Hospital, western Iraq. Saudi Med. J. 2009. 30(10):1296-1300.

\title{
العوامل المساهمة في وفيات الفترة المحيطة بالو لادة في عينة من مستثفيات في دائرة صحة بذاد الكرخ خلال ( نيسان 2018-اذار 2019)
}

\author{
فوزي هاشم عطثان -ابتسام فرج حسن - منير طالب سلمان- باسم محمد جواد
}

يعتبر معدل وفيات الفترة المحيطة بالو لادة مؤشرًا مهمًا للحالة الصحية للمجتمع ونوعية الخدمة الصحية التي يتم تقديمها للأم وجنينها خلال 28 أسبوعًا من الحمل وحتى 28 يومًا بعد الولادة ، فهنالك عو امل كثيرة تهدد حياة الأمهات وجنينهم. لذا هدفت هذه الدر اسة إلى حساب ذلك المعدل وتحديد العو امل المساهمة لوفيات الفترة المحيطة بالو لادة وذلك عن طريت دراسة الملفات الطبية للوفيات بأثر رجعي في ثناثة مستشفيات في بغداد الكرخ هي اليرموك , مدينة الأماميين الكاظمين و المحمودية العام لمدة عام واحد تبدأ من 1 أبريل 2018 لنهاية مارس 2019و اهم النتائج ,معدل وفيات الفترة المحيطة بالو لادة هى 45 لكل الف ولادة حية و اهم العوامل التي ساهمت في تلك الوفيات وجود ارتباط مهم بين العمر الحملي ، طريقة الولادة ، مكان الولادة و التوائم 